\title{
Mukayeseli Türkçe ve Fransızca Durûb-ı Emsâl'deki Türk Atasözleri
}

\section{Turkish Proverbs in Comparative Turkish and French Durûb-ı Emsâl}

\author{
Ebubekir Eraslan ${ }^{1}$ (1)
}

${ }^{1}$ Muğla Sıtkı Koçman Üniversitesi, Türk Dili Bölümü, Muğla, Türkiye

ORCID: E.E. 0000-0003-3713-1242

Sorumlu yazar/Corresponding author: Ebubekir Eraslan,

Muğla Sıtkı Koçman Üniversitesi, Türk Dili Bölümü, Muğla, Türkiye

E-mail: ebubekireraslan@gmail.com

Bașvuru/Submitted: 16.09 .2020

Revizyon Talebi/Revision Requested: 13.11.2020 Son Revizyon/Last Revision Received: 19.11.2020 Kabul/Accepted: 20.11 .2020

\section{Atıf/Citation:}

Eraslan, E. (2020). Mukayeseli Türkçe ve Fransızca Durûb-1 Emsâl'deki Türk atasözleri. TUDED 60(2), 539-559.

https://doi.org/10.26650/TUDED2020-0054

\section{ÖZET}

Bir ulusun geçmişten günümüze kadar tecrübe ettiklerini içinde barındıran atasözleri, Orhun yazıtlarından beri Türk yazı dilinde kullanılmaktadır. Atasözlerimizi derleyen ilk araştırmacı olan Kaşgarlı Mahmut'tan, XIX. yüzyıla kadar yazarların atasözlerini eserlerinde kullandığı görülmektedir. Tanzimat'la birlikte başlayan yenileşme ve değişme hareketleri kapsamında, atasözlerinin başlı başına derlendiği eserler kaleme alınmıștır. Șinasi'yle başlayan atasözlerini bir araya getirme faaliyetleri, İmparatorluğun son zamanlarına doğru aydın kesim arasında geniş bir karşılık bulmuştur. Bu karşılığa istinaden Türk atasözlerinin derlendiği yeni kitapların ortaya çıkmasıyla birlikte, Türk ve Fransız atasözlerinin aynı kitapta yer aldığı derlemelerin de yazıldığı görülmüştür. Üstelik XIX. asır ve XX. asrın başlarında yapılan FransızcaTürkçe, Türkçe-Fransızca atasözleri derlemeleri, diğer Batı dillerinden Türkçeye veya Türkçeden Batı dillerine yapılmamıştır.

Türk ve Fransız atasözleri derlemelerinin 1928'den evvelki üçüncü ve son eseri Mukayeseli Türkçe ve Fransızca Durûb-ı Emsâl olmuştur. Galatasaray Lisesi öğretmeni olan İzzet Hamid'in yazdığı bu eser, üç eserin arasında en hacimlisi ve en bol örneklisi olanıdır. Eserde toplamda 332 Türk atasözü yer almaktadır. Yazarın kişisel tercihlerine göre derlenen bu atasözü kitabı, hem iki dilli bir atasözü derlemesidir hem de Türk atasözleri derlemeleri içerisinde sahip olduğu özelliklerle farklı bir yerdedir.

Anahtar Kelimeler: Atasözü, Türkçe, Fransızca, İzzet Hamid, iki dillilik

\section{ABSTRACT}

Proverbs, which reflect what a nation has experienced throughout the ages, have been used in the Turkish written language since the Orkhon inscriptions. Mahmut of Kasgarli, the first researcher to compile our proverbs, found that authors have used proverbs in their works until the nineteenth century. The activity of gathering the proverbs, which first started with Sinasi, found a wide response among intellectuals toward the end of the Empire. While new books comprising Turkish proverbs based on this response have emerged, other compilations include both Turkish and French proverbs in the same book.

The third and last work of Turkish and French proverbs before 1928 the most voluminous and most exemplary of the three was Mukayeseli Durûb-ı Emsâl. Written by Izzet Hamid. Comprising a total of 332 Turkish proverbs. Compiled, according to the personel preference of the author, this proverb book is both a bilingual compilation of proverbs and it is in a different position with the features of Turkish proverbs.

Keywords: Proverbs, Turkish, French, Izzet Hamid, bilingualism 


\section{EXTENDED ABSTRACT}

Proverbs are oral literature products reflecting the material and spiritual values of a nation. Many poets and writers, starting from the Orkhon monuments, until the nineteenth century, used more, or less proverbs in their works. While the word sav was used to express the proverb in the beginning, it is seen that the word mesel, which was inherited from Arabic, was used later. However, it is known that the definition the word of ancestors is frequently used in anonymous works and until the tweentieth century.

As a reflection of the nationalist movements that spread all over the world following the French revolution, in the Ottoman geography in the nineteenth century, a Turkish mania, emerged through proverbs, idioms, curses, riddles, and so on, with books on these subjects beginning to be written independently.

Sinasi, who initiated the new literature, was the first to compile an independent book of proverbs, and increasing popularity was then observed in this field during the Tanzimat period and especially after the second constitutional period, under the influence of Ziya Gokalp.

Due to Turkey's geographical location near the West, the influence of French. The dominant language of the nineteenth century had increased. In order to learn the language, first foreigners, and then Turks wrote Turkish-French and French-Turkish works. Even in dictionaries written from Western languages to Turkish and from Turkish to Western languages, French has an advantage. The same is true in Turkish-French proverbs. When the literature is examined, only French proverbs were preferred to Turkish proverbs in Western languages until the nineteenth century and in the first quarter of the tweentieth century. Sinasi continued the compilation of Turkish-French proverbs that started with Jean D. Démétriades in 1888, with Mehmed Emin in 1891, and finally with Izzet Hamid in 1923.

Galatasaray High School teacher Izzet Hamid wrote a comparative work of 64 pages in Turkish and French called Durûb-ı Emsâl in 1923. As both the compiler and translator of the proverbs in the book. These related to each other by the crescent and star motif. Which, with a few exceptions, began with a Turkish proverb, and was followed by a French translation. In this study, the French proverb is given through the - sign in the same motif, and is translated into Turkish immediately following. Untranslated Turkish proverbs have also been included.

Turkish proverbs were translated with rika and written in verse. Untranslated Turkish proverbs and French proverbs are written in bold, whereas others are not. The French equivalent of the untranslated Turkish proverb is given in italics, while other French translations, and proverbs are not in italics.

A total of 332 proverbs were identified in the work, including 232 in the moon and star motifs, 55 in parentheses as synonyms of these 232 proverbs, and 45 in the same motif as close meaning. 
The personal preferences of the author are in question in the selection and arrengement of the Turkish and French proverbs in the comparative Turkish and French work Durûb-ı Emsâl, which also has no preface. However, the outer and inner cover of the work, which we can call foreword, show a couplet by Nabi and Ziya Pasha, a word by Sinasi, and a Turkish proverb.

Considering the whole work, the following can be said about Turkish proverbs:

- Some proverbs are given in parentheses with their close meanings.

- The close meanings of some Turkish proverbs with the crescent and star motif are also mentioned.

- Some of the adverbs are included in the proverbial collection.

- It seems that some proverbs are incomplete.

- Quotations find their place in the dictionary.

- Some idioms are included in the proverbial collection.

- The proverbs given in parentheses are meaningful proverbs close to the ones given before.

- The contemporary use of some proverbs is included.

- Different versions of proverbs, which differ in their contemporary, use are included.

- Some proverbs are obvious.

- Few known proverbs in Turkish are now encountered in the work.

- Different variants of the words in some proverbs are shown in parentheses. 


\section{GİRIŞ}

Türk dilinin zenginlik göstergelerinden biri olan atasözleri, asırladır Türk milletinin duygusunu, hüznünü, sevincini vb. birçok özelliğini taşıyan ve taşımaya devam eden sözlü edebiyat ürünleridir. İlk yazılı belgelerimiz olan Orhun âbidelerinden bu yana, pek çok eserde atasözlerine yer verilmiş, bazen de atasözlerinin derlendiği müstakil kitapların yazılmıştır.

Türk atasözlerinin yazıya geçirilmiş en eski örneklerine VIII. yüzyılda taşlara kazınan Orhun yazıtlarında rastlanılmaktadır. Bunlar ilk defa Ahmet Caferoğlu (1929) tarafindan ele alınmıştır. Uygur dönemi metinleri arasında bulunan on üç atasözünün yayımı da Reşit Rahmeti Arat tarafından yapılmıştır. (Zülfikar, 1988: 321-328)

XI. yüzyılda Kaşgarlı Mahmut, Divanu Lugati 't-Türk'e malzeme oluşturmak amacıyla atasözleri derlemiştir. Böylece Kaşgarlı Mahmut, ilk Türk atasözü derleyicisi unvanını almıştır. Ahmet Bican Ercilasun'un (2000) son tespitine göre de bu eserde toplamda iki yüz altmış altı adet atasözü bulunmaktadır.

Bir ahlak ve siyaset kitabı olan Kutadgu Bilig'de, Edip Ahmed Yükneki'nin dörtlüklerden oluşan Atabetü'l Hakayık isimli eserinde, Dede Korkut Kitabı'nda da birçok atasözü kullanılmıştır.

Tanzimat sonrasında Şinasi’nin başlattığı Türk atasözlerini bir araya getirme faaliyeti, İmparatorluğun yönünü ve yüzünü Avrupa'ya çevirmesiyle XIX. yüzyılın sonu ve XX. yüzyılın başında Fransızca-Türkçe atasözlerinin derlendiği/karşılaştırıldığı atasözleri kitaplarıyla devam etmiştir. Bu alanda yazılmış üçüncü ve son eser, Galatasaray Lisesi muallimi İzzet Hamid'in yazdığı Mukayeseli Türkçe ve Fransızca Durub-ı Emsal adlı kitaptır.

İzzet Hamid [Ün]; eserinde Türk ve Fransız atasözlerini neye göre seçtiğini belirtmeden, ön söz yazmadan, atasözlerini sıralarken herhangi bir numara vermeden, ay yıldızla böldüğü alanda önce Türk atasözlerini vermiş, sonrasında da bu atasözlerinin Fransızca çevirisini yazmıştır. Bu sefer aynı ay yıldızı bitirmeden de Fransız atasözlerine yer vermiş, hemen ardında da Fransız atasözlerinin Türkçe tercümesini yazmıştır. Biz de bu çalışmamızda yazarın ay yıldızla ilk olarak verdiği - tercüme atasözlerine değil - Türk atasözlerine yer verdik.

\section{Atasözü}

\subsection{Atasözünün Tanımı}

Almancada Sprichwort, Arapçada mesel, Farsçada pend, Fransızcada proverbe, İngilizcede proverb, Slav dillerinde posloviçe denilen atasözü için Türkçede "ata sözleri, atalar sözleri, atalar sözü, büyükler sözü, darb-1 mesel, deme, demece, deyiş, dimece, durub-1 emsal, eskiler sözü, hikmetü'l-avam, mesel, meşhur sözler, pend, sanıka, oranlama, özlü söz, özlü sözler, teselleme, ulular sözü’ gibi terimler farklı dönem ve bölgelerde kullanılmıştır. (Zülfikar, 1988: 321-328; Eyüboğlu, 1973) 
Atasözüyle ilgili şu tanımlar yapılmaktadır:

- Mesel veya atasözü bir fikri savunmada; bir olayı, bir davranışı yorumlamada, yermede kullanılan etken bir dil aracıdır; ya tam ya da öznesi, yüklemi veya tümleci eksik bir önermedir. (Eyüboğlu, 1973)

- Bir ulusun değer yargılarını anlatan özlü sözlerdir. (Çotuksöken, 1983)

- Atalarımızın; uzun denemelere dayanan yargılarını genel kural, bilgece düşünce ya da öğüt olarak düsturlaştıran ve kalıplaşmış şekilleri bulunan kamuca benimsenmiş özsözlerdir. (Aksoy, 1965)

Bize göre de atasözü; bir milletin geçmişten günümüze kadar yaşayıp tecrübe ettiklerini kısa ve özlü bir şekilde anlatan kalıplaşmış ifadelerdir.

Yazı dilinde ilk kez Orhun âbidelerinde karşılaştığımız atasözlerinin, İslamiyet'ten önceki devirde "söz, haber, mesaj, nutuk, şöhret" anlamlarına gelen ve sa- fiilinden türeyen "sabsaw” kelimesi ile karşılandığı, Kaşgarlı Mahmud'un Divanu Lugati 't-Türk'teki kullanımından anlaşılmaktadır. Türklerin İslamiyet'i benimsemelerinden sonra gerek şekil gerekse içerik bakımından İslamî kültür etkisinin görüldüğü ilk eser olan Kutadgu Bilig'deyse atasözü karşılığg olarak mesel teriminin kullanılmaya başlandığg bilinmektedir. Zikrettiğimiz bu son eserdeki kullanımdan itibaren Batı Türkçesinde bu terimin yaygınlaştığı, bununla birlikte “örnek vermek" anlamına gelen "darb-1 mesel” ve bunun çoğulu "durûb-1 emsâl” terimlerinin de kullanılmaya başlandığı görülmektedir. Bunun yanında, Veled Çelebi İzbudak’ın neşrettiği bir derlemenin isminden de anlaşılacağı üzere "atalar sözü” teriminin de sıklıkla kullanıldığı, hatta "atalar sözü" teriminin aslında XIX. asra kadar çoğunlukla tercih edildiği de tespit edilmiştir. (Zülfikar, 1988)

Cumhuriyetin ilk yıllarından itibaren "darb-1 mesel, mesel” sözcüklerinin yerini “atasözü ve atalar sözü” alır. Günümüzde kullanılan “atasözü” şekliyse ilk kez 1965 'te TDK tarafından çıkarılan Yeni Yazım Kılavuzu’nda görülür. (Zülfikar, 1988: 321-388)

\subsection{Atasözlerinin Genel Özellikleri}

Alan literatür bilgisi göz önüne alındığında atasözlerinin genel özellikleriyle ilgili şunlar söylenebilir:

- Anonimdir.

- Toplumun ortak malidir.

- Yüzyılllarca süren uzun deneme-yanılma ve gözlemlere dayanılarak oluşturulmuştur.

- Kısa ve öz bir anlatıma sahiptir.

- Kalıplaşmış sözlerdir.

- Bir yargı ya da kesinlikle uyulması gereken bir kural ve ögüt özelliği taşır.

- Söz sanatları açısından zengindir. 
- Geniş zaman ve emir kipi başta olmak üzere diğer kipler kullanılır.

- Genellikle mensur olmakla birlikte manzum atasözleri de vardır.

\subsection{Türk Edebiyatında Atasözü Kullanımı}

\subsubsection{Divan Edebiyatında Atasözü Kullanımı}

XIII. yüzyıldan itibaren Anadolu sahasında cereyan eden ve XIX. yüzyılın sonuna kadar devam eden Divan edebiyatında atasözü kullanımının oldukça yoğun olduğu gözlemlenmektedir. İlk temsilcilerinden itibaren bu edebiyatın gerek şiir gerekse nesir sahasında atasözü ve deyimlerin kullanımı, ifadeyi güçlendirmek için kullanılan en önemli unsurlardan birisi olmuştur. Bu edebiyatın mensubu olan neredeyse tüm şair ve yazarların eserlerinde az veya çok atasözlerini kullandıları görülmektedir. Başta Necati Bey olmak üzere Tâli'î, Sadrî, Atâyî, Nâbî, Sâbit, Râgıp Paşa, Sünbülzâde Vehbî, Sürûrî, Vâsıf, Fâzıl, Şeyh Gâlib, İzzet Molla, Yenişehirli Avnî, Şinâsî ve Ziya Paşa gibi şairler şiirlerinde atasözlerine sıkça yer vermişlerdir. (Şentürk; Şentürk ve Kartal, 2007: 265-315) Burada adını geçirdiğimiz bazı şairlerin şiirlerinde atasözlerine sıkça yer vermeleri onların benimsedikleri şiir üslubuyla da ilişkilidir. Bu noktada XVII. yüzyıldan itibaren başını Nabi'nin çektiği Hikemî üslubun atasözü kullanımına elverişli olduğu bilinmektedir.

Divan edebiyatının farklı konular çerçevesinde oluşturulan uzun soluklu nazım biçimi olan mesnevilerdeyse atasözü kullanımının daha yoğun olduğu görülmektedir. Özellikle ahlak ve nasihat gibi konularda yazılan mesneviler âdeta birer atasözü depolarıdır. Bu mesnevilere en güzel örnek pendnâmelerdir. Yine bazı şairlerin çocukları için yazdığı nasihatname türündeki eserlerde de çok sayıda atasözünün kullanıldığı görülmektedir. Bu noktada XVI. yüzyıl şairi Keşfî'nin Te'dîbnâme'si, Nâbî'nin Hayriyye'si ve Sünbülzâde Vehbî'nin Lutfiyye'si hatırlanması gereken başlıca eserlerdendir.

\subsubsection{Halk Edebiyatında Atasözü Kullanımı}

Halk edebiyatının ürünleri arasında yer alan masallar, halk hikayeleri, efsaneler ve fikralarda birçok atasözü kullanılmıştır. Bunun yanında Halk şiirinin temsilcileri olan âşık ve şair mutasavvıflar da şiirlerinde atasözü ve deyimlere yer vermiştir. Ancak bunlar arasında Levnî’nin Atalarsözü Destanı ve bu destana Salburcuoğlu, Menguşî, Şikarî, Erbabî, Talibî, Miratî, Şemî, Mevcî, Gedayi, Havayi, Merdümî, Hakî, Lutfî, Refikî, Kadrî, Figanî, Bedrî, Yesarî, Gufranî, Mestî, Dervişî, Rahmî, İhrakî, Nâilî ve Vasıf gibi şairlerin yazdıkları nazire niteliğindeki destanlar adeta bir atasözü hazineleri olmaları bakımından ayrı bir öneme sahiptir. (Banarlı, 2004)

\section{Türkçe ve Fransızca Atasözleri Kitapları}

1928 yılına kadar yazılmış üç adet Türk ve Fransız atasözlerinin derlendiği kitap bulunmaktadır. Bizim çalışmamıza konu olan eser, bu üç kitabın sonuncusu ve en hacimli olanıdır. Bu üç eser sırasıyla şunlardır: 


\subsubsection{Durûb-ı Emsâl-i Osmaniye ve Franseviye}

Türkçe, Fransızca ve Rumca öğretmeni olan Jean D. Démétriades eserini 1888 yılında İstanbul'da Matbaa-i Ebuzziya'da bastırmıştır. Eserdeki tüm Türk ve Fransız atasözleri numaralandırılmıştır. Kitabın sol tarafında Fransız sağ tarafında da Türk atasözleri sıralanmıştır. Toplamda 353 atasözüne yer verilen eser, 25 sayfadan oluşmaktadır. Eserin Türkçe ve Fransızca olan ön sözlerinde aynı ifadelere yer verilmediği görülmektedir.

\subsubsection{Durûb-ı Emsâl-i Fransevî Lügatçesi}

1891 yılında İstanbul Kasbar Matbaası'nda eski hariciye katiplerinden Mehmed Emin tarafından neşredilmiştir. Eserde 122 atasözü bulunmaktadır. Atasözlerinin önce Türkçesi, Türkçesinin karşısına da Fransızcası verilmiştir. Atasözleri Fransızcanın alfabetik sırasına göre herhangi bir numaralandırmaya bağlı kalınmadan yazılımıştır. Eser 30 sayfadan oluşmaktadır.

\subsubsection{Mukayeseli Türkçe-Fransızca Durûb-ı Emsâl}

Osmanlı Türkçesiyle yazılmış eserin kapağında eserin basım yılının hicrî 1339 (1921), Fransızca olan kapağında da 1923 olduğu yazmaktadır. (İzzet Hamid, 1923) Bunun bir hata mı veyahut bilinçli bir tercih mi olduğunu bilmesek de eserin basım yılı kaynaklarda istisnasız hep 1923 olarak gösterilmektedir. Bu yüzden biz de tarihlendirmede 1923 yılına bağlı kaldık.

Galatasaray Sultanisi öğretmenlerinden İzzet Hamid'in yazdığı eser, İstanbul'da İkdam Matbaası'nda basılmıştır. İzzet Hamid, eserin hem derleyicisi hem de Türk-Fransız atasözlerinin karşılaştırmacısı/mütercimidir.

Eser 64 sayfadan mürekkeptir. Eserde birbiriyle bağlantılı atasözlerini ayırmak için ay yıldız motifi kullanılmıştır. Bu ay yıldız motifleri birkaç istisna dışında Türk atasözüyle başlar, hemen sonrasında Fransızca tercümesine yer verilir. Aynı motif içerisinde - işareti gösterilerek bu sefer Fransız atasözü verilmiş, hemen ardından bunun Türkçe tercümesine geçilmiştir.

Türk atasözleri rikayla, tercüme Türk atasözleri de nesihle yazılmıştır. Tercüme olmayan Türk atasözleriyle Fransız atasözleri kalın yazılmıştır, diğer atasözleri kalın yazılmamıştır. Tercüme olmayan Türk atasözlerini Fransızca karşılığı eğik yazıyla verilmiştir. Diğer Fransızca tercüme ve atasözleri eğik yazılı halde değildir.

Eserde herhangi bir ön söz yoktur. Fakat ön sözde belirtilebilecek ifadelere sahip Nabi ve Ziya Paşa'dan birer beyit, Şinasi'den bir cümle ve bir de Türk atasözü eserin Osmanlı Türkçesiyle yazılmış dış ve iç kapağında yer almaktadır. Yazarın dış ve iç kapakta alıntıladığı sözler sırasıyla şu şekildedir: 


\begin{tabular}{|c|}
\hline Dış Kapak \\
\hline Durûb-1 emsâl ki hikmetü'l-avamdır. \\
Lisanından sadrolduğu bir milletin mahiyet-i efkârına delalet eder. \\
Şinasi \\
Sözde durûb-1 mesel irâdına söz yok amma \\
Söz odur âleme senden kala bir darb-1 mesel. \\
Nabi
\end{tabular}

\begin{tabular}{|c|}
\hline İç Kapak \\
\hline Lisanından sadrolduğu bir milletin mahiyet-i efkârına delalet eder. \\
Şinasi \\
Atalar sözünü tutmayanı yabana atarlar. \\
Darb-ı Mesel \\
İrsâl-i meselde mesele yoktur \\
Bu şivede söz eğerçi çoktur. \\
Ziya Paşa
\end{tabular}

İzzet Hamid [Ün] eserindeki atasözlerine herhangi bir numara vermemiştir. Aşağıda verdiğimiz numaralandırmalar bize aittir.

\subsection{Mukayeseli Türkçe ve Fransızca Durûb-ı Emsâl'in Yazarı İzzet Hamid'in Hayatı ve Eserleri}

1895 yılında İstanbul'da doğan İzzet Hamid, Galatasaray Lisesi’nden 1914 yılında mezun olmuştur. Özemre'nin (2006: 70) belirttiği üzere adı Âbidin İzzet Hamid'dir. Fakat bu bilgi sadece burada yer almakta olup başka hiçbir yerde böyle bir malumat yer almamaktadır. Babası İsmail Hamid olup Türk edebiyatının önemli isimlerinden Haldun Taner'in de dayısıdır. (Aslan, 2017: 4-5)

Galatasaray Lisesi'nde Fransızca öğretmenliği görevini yapmaya başladıktan sonra, aynı okulda sırasıyla başmuavinlik ve 3 Kasım 1950'den 3 Temmuz 1951'e kadar da müdür vekilliği görevini yürütmüştür. Buradaki görevi süresince ailesiyle birlikte Lise' deki lojmanda kaldığı ve okulu 24 saat üzerinden 24 saat sıkı bir denetime tâbi tuttuğu (Özemre, 2006: 24) yazılmaktadır. Yine Özemre (2006: 70) aynı lisede 17 Kasım 1948 Çarşamba günü öğleden sonra okulun konferans salonunda Galatasaray Lisesi'ne en az 25 y1l hizmet etmiş olan ve hâlâ Lise'de hoca 
olarak çalışan on hocaya jübile yapıldığgnı ve İzzet Hamid Ün'ün de başmuavin olarak bu on kişiden biri olduğunu yazmaktadır. Başka bir hatıra kitabında da İzzet Hamid Ün'ü herkesin tanıdığı ve onu çok sevdiği kaydedilmektdir. (Aray, 1959: 192) Ayrıca yazarın öğrencileri arasında “yani, yani” sözüyle anıldığı da söylenmektedir. (Oktay Aras Kitaplı̆̆ı, 2020)

Galatasaray Lisesi'nden sonra Çapa Eğitim Enstitüsü'ne Fransızca öğretmeni olarak tayin edilen yazar, soyadı kanunu çıktıktan sonra Ün soyadını almıştır. Çoşkunlar’a (1961: 57) göre 16 Temmuz 1960'da, Oktay Aras'a (2020) göre de 17 Temmuz 1960'da vefat etmiştir.

Eserleri: Méthode Directe Et Combinée Pour L'étude De La Langue Turque (1922), Mukayeseli Türkçe ve Fransızca Durub-1 Emsal (1923), Méthode Directe et Combiné Pour l'Etude De La Langue Turque (1933), Fransizca Ders Kitabı IV-V-VI (Lise Sinıf I, II, III), A New Dialect And Combined Method For The Study Of The Turkish Of Today (1951), Turkish Of Today (1951), Langue Turque (1954), Pratik Fransızca Konuşma Kılavuzu (1959), Teknik Öğretimde Öğrencilere Faydalı Fransızca Okuma Parçaları (1955), Langue Turque (1962).

Yazarın yukarıda verdiğimiz eserlerinin çoğunun birden fazla basımı yapılmıştır.

\subsection{Mukayeseli Türkçe ve Fransızca Durûb-ı Emsâl'deki Türk Atasözleri}

1923 tarihli Mukayeseli Türkçe ve Fransızca Durûb-ı Emsâl'deki Türk Atasözleri adlı eserdeki tercüme olmayan Türk atasözleri tarafımızdan verilen numaralandırmaya bağlı kalınarak aşağıda sıralanmıştır.

1. Dosta çok varan ekşi yüz görür.

2. Mangal kenarı kış gününün lâlezarıdır. (Ateş k1ş gününün meyvesidir.)

3. Karınca kararınca.

3. 1. Kişi ayağını yorganına göre uzatmalı.

3. 2. Insan bacağına göre adımını atmalı.

4. Kötülük eden kötülük bulur.

4. 1. Zalim ettiğini bulur. (İyi söylersen iyi işidirsin, kötü söylersen kötü işidirsin. Kimsenin ahı kimsede kalmaz. Cenab-1 Hak imhal eder, ihmal etmez. Her koyun kendi bacağından asılır.)

5. Gök çok gürleyince az yağmur yağar.

6. Büyük lokma ye, büyük söz söyleme.
7. Suya varmadan paçaları sıvıyor.

8. K1z anasından görmeyince sofrayı kaldırmaz. 8. 1. K1z anadan görmeyince öğüt almaz.

9. Halkın sesi, hakkın sesi.

10. Haset eden mahrum kalır.

10. 1. Tamahkârın gözünü toprak doyurur.

11. İğneyi evvela kendine sok, sonra çuvaldızı ele.

12. Devletliye dokun geç, fakirden sakın geç.

13. Parasını aziz eden kendisini zelil eder. (Varını veren utanmaz. Zelil adam tamahkâr olur. Vermekle mal tükenmez.) 
14. Devlet ayağına dolaşır.

15. Karga bana söyledi.

C.

16. Nasıl yaşarsak öyle ölürüz. (Hile ile iş gören mihnet ile can verir.)

17. Anlatılışa göre verirler fetvayı.

18. Adın çıkacağına canın çıksın. (Adı çıktı dokuza inmez sekize.)

19. Dinsizin hakkından imansız gelir.

20. Anasından emdiği burnundan geldi.

C.

21. Aşağı tükürsem sakalım, yukarı tükürsem bıyığım. (İki cami arasında kalmış beynamaza döndü.)

C

22. Huy canın altındadır.

22. 1. Can çıkamayınca huy çıkmaz.

22. 2. Alışmış (dadanmış) kudurmuştan beterdir.

23. Kimin arabasına binerse onun türküsünü çağırır. (İyi gün dostu)

C.

24. Kuşu kuşla avlarlar.

24. 1. Kurdu kurt ile avlamalı.

C

25. Kediye ciğer emniyet edilmez.

25. 1. Kurda koyun inanılmaz.

25. 2. Kediye peynir tulumu birakılmaz.

26. Amasya'nın bardağı biri olmazsa bir daha.

26. 1. El için kuyu kazan evvela kendi düşer.

26. 2. Kişi ettiğini bulur.

26. 3. Ne dilersen eşine o gelir başına.

26. 4. Herkesin ettiği yoluna gelir.

26. 5. Etme bulma dünyas1.

C

27. Eski dost düşman olmaz, yenisinden vefa gelmez.

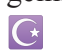

28. Suyu bardakta, gemiyi duvarda seyretmeli.

29. Köpeği an, çomağı yanı başında.

30. (Bir kapıyı bend ederse bin kapı eyler küşad.)

31. Köpeği öldürene sürütürler.

\section{C}

32. Kaz gelen yerden tavuk esirgenmez.

\section{*}

33. Kel ölür sırma saçlı olur; kör ölür badem gözlü olur.

34. Eşeği oduna çağırmışlar «ya odun eksik ya su» demiş.

35. Sanat altın bileziktir.

36. Kebap pişerken uyumak caiz değil.

\section{(}

37. Gün doğmadan neler doğar. (Günden doğmadan meşime-i şebten neler doğar.)

38. Almaya şahin, vermeye karga.

38. 1. Borç güle güle gider, ağlaya ağlaya gelir.

39. Boş lakırtı karın doyurmaz.

40. Her işin sonuna bak.

C

41. Başa yazılan gelir.

42. Halep orada ise arşın burada. (Yiğit meydanda belli olur. İşte k1liç işte meydan.)

43. Kısmetinde varsa kaşığında çıkar.

44. Yerinde tekrir baş ağrıtmaz. (Doğru söze akan sular durur.)

C

45. Aç tavuk kendini buğday ambarında sanır. C

46. Aç ayı oynamaz. 
47. Ağlamayan çocuğa meme vermezler.

C.

48. Aç ölmekten tok ölmek evladır.

C.

49. Ayinesi iştir kişinin lafa bakılmaz.

49.1. Şahsın görünür rütbe-i aklı eserinde.

C

50. Bal bal demekle ağız tatlı olmaz.

\section{C}

51. Kurt dumanlı havayı sever.

C.

52. Islanmışın yağmurdan pervası olmaz.

53. Elifi görse mertek sanır.

C

54. Bal tutan parmağını yalar.

55. Sona kalan dona kalır.

C.

56. Besle kargayı oysun gözünü.

57. Korku dağları aşırır. (bekler.)

58. At çalındıktan sonra ahırın kapısını kapar.

59. Kedinin bulunmadığı yerde fare baş kaldırır.

(

60. Bir çiçekle yaz olmaz.

61. Vurursan acit, yedirirsen doyur.

C.

62. Bugünkü yumurta yarınki tavuktan iyidir.

C.

63. Böyle efendinin hürmetkârı böyle olur.

64. At alan Üsküdar'1 geçti.

C.

65. Debbağ sevdiği deriyi yerden yere vurur.

66. Her derdin bir devası vardır.

67. Hüküm galibindir.

67. 1. Akvanın iddiası daima âlâdır.

(
68. Azmin elinden hiçbir şey kurtulmaz.

68. 1. Muradın elinden ne kurtulur.

69. Damlaya damlaya göl olur.

70. Deliye taş atma. (Kel yanında kabak denmez.)

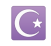

71. Adamın kıymetini adam bilir.

\section{C}

72. Bir musibet bin nasihatten yeğdir.

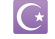

73. Atılan ok geri dönmez.

73. 1. Ok yaydan çıktı.

74. Anasının karnında dokuz ay on gün nasıl durmuş?

75. Akılsız başın zahmetini ayak çeker.

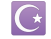

76. Merkebe altın semer vursalar yine merkep yine merkep.

77. Tatsız çorbaya tuz, akılsız kafaya söz kâr etmez.

78. Boş atıp dolu tutuyor.

79. Demir tavında yaraşır.

\section{C}

80. Bir akçe ile dokuz kubbeli makam yapar.

81. Az tamah çok ziyan getirir.

82. Acele işe şeytan karışır.

82. 1. Tiz-i reftar olanın payine damen dolaşır.

82. 2. Erişir menzil-i maksuduna aheste giden.

83. Ha Hoca Ali, ha Ali Hoca. (Ayvaz kasap hep bir hesap.)

84. Rüzgar esmeden yaprak oynamaz.

85. Herkesin çektiği dilinin belasıdır. (Dilini tutan başını kurtarır.) 
86. Allah kulunun götüreceği kadar verir.

86. 1. Garip kuşun yuvasını Allah yapar.

87. İki cambaz bir ipte oynamaz.

88. İki karpuz bir koltuğa sığmaz.

89. Tabiattan bahsolunmaz. (Mezhepten bahsolunur, meşrepten bahsolunmaz.)

90. Süt içerken ağzı yandı, yoğurdu üflüyor.

92. Her sefanın bir cefası, her cefanın bir sefası.

92. Kedi yavrusunu yiyeceği vakit «fareye benziyor» demiş.

93. İki kaptan bir gemiyi batırır.

94. Gemisini kurtaran kaptandır.

95. Müsademe-i efkardan barika-i hakikat çıkar.

96. İtibar samur kürke.

97. Koyunun bulunmadĭğ yerde keçiye Abdurrahman Çelebi derler.

C.

98. İnsanın söylemezinden, suyun şarlamazından.

98. 1. Yavaş atın tekmesi yavuz olur.

99. Attan indi eşeğe bindi.

100. Hak söz acıdır.

101. Dün yumurtadan çıktı bugün kabuğunu beğenmiyor.

102. Bin ölçüp bir biçmeli.

C

103. Ölüyü gören hastalığa razı olur.

104. Armut piş ağzıma düş.

C
105. Bu sıcağa kar mı dayanır!

106. Ezmanın tagayyürü ile ahkam-1 tagayyür eder.

107. Elinin hamuruyla erkek işine karışma.

108. Her kafadan bir ses.

109. Taamın azından, kelamın çoğundan Allah ırak eyleye. (Evvel taam, sonra kelam)

110. Tencere yuvarlandı kapağını buldu.

111. Varlığa darlık olmaz.

111. 1. Altın anahtar kale kapılarını açar.

111. 2. Altın eli biçak kesmez.

111. 3. Çık çık eden nalçadır, iş bitiren akçedir.

111. 4. Rağbet güzel ile zengindir.

111. 5. Parayı veren düdüğü çalar.

111. 6. Derviş para ile biter her iş.

111. 7. Zengin arabasını dağdan aşırır, zügüurt ovada yolunu şaşırır.

111. 8. Akçesi ak olanın bakma yüzün karasına.

111. 9. Akçeli adamdan dağlar korkar.

112. Zaman büyük bir muallimdir.

112. 1. Zaman insana her şeyi öğretir.

113. Sükut etmek gibi nadana cevap olmaz.

\section{C}

114. Hakimsiz, hekimsiz bir memlekette oturma.

115. Öküzün altında buzağı arıyor.

116. Zahmetsiz bal yenmez.

117. Ada bana, adayım sana. (Her hizmet bir menfaat mukabilidir.)

118. Göz iki, kulak iki, ağız tek; çok görüp çok işitip az söylemek gerek.

118. 1. Bir söyle bin işit.

118. 2. Söz gümüşse sükut altındır. 
119. Kişi doğduğu yerde değil doyduğu yerdedir.

120. Âlemin ağz1 torba değil ki büzesin.

C.

121. Uzaktan davulun sesi hoş gelir.

122. Adam odur ki ikrarından dönmeye. (Tükürdügünü yalamaz.)

C.

123. Damdan düşen damdan düşenin hâlini bilir.

(Başa gelmeyince bilinmez.)

C.

124. Latife latif gerek.

125. Sanatı hor gören boynuna torba takar.

126. Terzi kendi söküğünü dikemez.

127. Merhametten maraz hasil olur.

128. Yatan yılanın kuyruğuna basmamalı.

C

129. Herkesin nabzına göre şerbet verir. (Herkesin suyuna göre gider.)

130. Rüzgara tüküren yüzüne tükürür.

C.

131. Haydan gelen huya gider. (Haramdan gelen harama gider.)

132. Çok gülen çok ağlar.

133. Herkes evinde ağadır.

133. 1. Herkes kendi âleminin padişahıdır.

133. 2. Her horoz kendi çöplüğünde öter.

134. Tilkinin gezip (dönüp dolaşıp) geleceği yer kürkçü dükkanıdır.

C.

135. Su destisi su yolunda kırılır. (Çeşmeye gidenin destisi kır1lır.)

136. İttihattan kuvvet doğar.

C
137. Astarı yüzünden pahal1.

138. Kapının kanadı kesenin ağzıdır.

139. Körün yanına varırsan sen de bir gözünü kapa.

C

140. Tatlı dil yılanı yerden (deliğinden) çıkarır. (Tatliya tatlı söyle.)

\section{C.}

141. Kös dinlemiştir, davula kulak vermez. (Gürültüye pabuç bırakmaz.)

\section{C}

142. Geç olsun da güç olmasın.

143. Sürücü ol ki bilici olasın.

143. 1. Kişiye bilmemek ayıp değil sormamak ayıptır.

144. Sabırla koruk helva olur, dut yaprağı atlas.

144. 1. Allah sabırlı kulunu sever.

144. 2. Sabrin sonu selamettir.

144. 3. Sabreden derviş muradına ermiş.

\section{C}

145. Kötürümden aksak, hiç yoktan torlak yeğdir.

\section{C}

146. Yerin kulağ 1 var.

\section{C}

147. Zurnayı biz çaldık, parsayı el topladı. (Biz cefayı çektik, eller sürdü sefayı.)

148. Bağ dua değil çapa ister. (Bakılırsa bağ olur, bakılmazsa dağ olur.)

C

149. El elden üstündür.

C

150. Ucuz alan pahalı alır. (Ucuz etin yahnisi tatsız olur.)

151. Görünen köy kılavuz istemez.

152. Her kimin bağ varsa yüreğinde dağ 1 var.

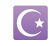

153. Oldu olacak kırıldı nacak. 
154. Her parlayan altın değildir.

155. Aldatayım diyen aldanır.

156. Ne kokar ne bulaşır. (Ne etliye karışır ne de sütlüye.)

157. Bir kötünün yedi mahalleye zararı vardır.

157. 1. Üzüm üzüme bakarak kararır.

158. Kişinin refikine nazar etmeli. (Deli deliden hoşlanır, imam ölüden. Karanın yanına varma kara bulaşır.)

159. Borçsuz adam yoksul beyden yeğdir.

C*

160. İnsan yanıla yanıla âlim olur.

161. Aza kanaat etmemiş çoğu bulamaz. (Azı bilmeyen çoğu hiç bilmez.)

162. Küçük taş baş yarar. (Ummadığın taş baş yarar.)

C.

163. Mihneti kendine zevk etmededir hüner. (Kazaya rıza lazımdır.)

C.

164. Ben öldükten sonra taş taş üstünde kalmasın.

C.

165. Olsa ile bulsayı yere ekseler yel ile yuf biter.

C.

166. İşitilmemiş cihanda haber olmaz.

C.

167. Yuvarlanan taş yosun tutmaz.

C.

168. Delikli taş yerde durmaz. (Boş çuval durmaz.)

C.

169. Kara haber tez duyulur.

C.

170. Dişin ağrıdığı yere dil dokunur.

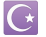

171. Sükut ikrardan gelir.

172. Akıl yaşta değil baştadır.

173. Efendinin nazarı ata tımardır.
174. Anlayana sivrisinek saz, anlamayana davul zurna az.

174. 1. Ârife bir işaret yeter. (Ârife tarif istemez. Ârif olan anlar. Ârife bir gül yeter kokmaya)

\section{C}

175. Yağmurdan kaçarken doluya tutuldu.

176. Kendi gözündeki merteği görmez de elin yüzündeki çöpü görür.

177. İyi dost kara günde belli olur.

178. Bahşiş atın dişine bakılmaz. (Dilenciye hıyar vermişler, eğri demiş.)

179. Dağ dağa kavuşmaz, insan insana kavuşur.

180. Gözden rrak olan kalpten de rrak olur.

181. Yenilen doymaz.

182. Büyük balık küçük balığı yutar.

\section{C}

183. Malın çokluğu ziyan vermez. (Artık mal göz çıkarmaz.)

*

184. Çok gezen çok bilir. (Çok yaşayan çok bilmez, çok gezen çok bilir.)

C

185. Büyük başın ağrısı büyük olur.

186. Hizmet etmeyen efendilik bilmez.

C

187. Gönülsüz köpek av avlamaz.

C

188. Aç kiminle olsa savaşır. (Aç kılıca sarılır.)

189. Herkesin bir delilik damarı var.

190. Düşenin dostu olmaz. (Garibin dostu olmaz.)

C

191. Herkes ektiğini biçer.

191. 1. Eken biçer.

192. Çok açılma, soğuk alırsın. 
193. Ekmek çiğnemeyince yutulmaz. (Evvel zahmet, sonra rahat.)

\section{C}

194. Çekirge bir sıçrar iki sıçrar üçüncüsünde ele geçer.

C

195. Kırkında saza başlayan kıyamette çalar.

C

196. Yangına körükle gidiyor.

C*

197. Ayağında donu yok, başına fesleğen takar.

C.

198. Köprüyü geçinceye kadar ayıya dayı derler.

199. Bülbüle raks zindandır. (Bülbülü altın kafese koymuşlar "ah vatanım" demiş.)

C.

200. Gül dikensiz olmaz.

C.

201. Yayı çok çekme kırarsın. (Ne yavuz ol asıl, ne yavaş ol basıl. Çok verme arsız olur, az verme hırsiz olur.)

C

202. Ümit ile kanaat eden açlıktan ölür.

C

203. Gönül kocamaz.

204. Ay1 vurulmadan postu satılmaz.

C.

205. Yaş yaşadıkça akıl başa gelir.

206. Sağlık varlıktan yeğdir.

207. Her şey vaktinde gerek.

C.

208. Her kemalin bir zevali, her zevalin bir kemali.

209. Baht olmayınca başta ne kuruda biter ne yaşta.

C

210. Araba kırılınca yol gösteren çok olur.

211. Bir kadeh mey kișinin cümle hicabın götürür. (İçtik üzüm suyunu, döktük yüzün suyunu.)

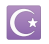

212. İyilik zayi olmaz.
213. Et ile tırnak arasına girilmez.

214. Ak1llı düşman akılsız dosttan iyidir.

C

215. Çivi çiviyi söker.

216. Haram helalden tatlıdır.

217. Kanaat gibi devlet olmaz.

217. 1. Kanaat tükenmez hazinedir.

C

218. Ev yeni, duvar yeni, eleğim seni nereye asayım.

219. Korkak bezirgan ne kâr eder ne ziyan.

220. Hangi gün var akşam olmadık.

C

221. Atalar sanatı oğlana mirastır.

222. Kör kadı diyecek kadar doğru söz işe yaramaz.

C

223. Gülü seven dikenine katlanır. (Bağban bir gül için bin hare hizmetkâr olur.)

224. Gelen gideni aratır.

225. Görünüşe aldanmamal1.

225. 1. Surete bakma sirete bak. (Her gördüğün sakallıyı baban mı sanırsın.)

C

226. Buldukça bunalır.

227. Zaman zamana uymaz.

228. Her ziyan bir ögüttür. (Her zararda bir hayır vardır.)

229. Fazla naz âşık usandırır. (İnsan her gün şeker yese bikar.)

230. Âlimi nasıl bilirsin kendin gibi.

C

231. Ecele çare olmaz.

232. Arayan bulur. 


\subsection{Mukayeseli Türkçe ve Fransızca Durûb-ı Emsâl'deki Türk Atasözlerinin Özellikleri}

Bozkurt ve Karadağ (2013: 179) İzzet Hamid'in eserinde 240, Eminoğlu (2010: 185) 2500 adet atasözünün yer aldığını söylemektedir. Fakat bu iki bilgi de doğru değildir. Bizim tespitimize göre ay yıldızlı motifler içerisinde 232; bu 232 atasözünün eş anlamlısı olarak parantez içinde yazılan 55, aynı kavram dünyasıyla ilgili ay yıldız motifi içerisinde sıralanan 45 adet atasözünün de eklenmesiyle eserde toplamda 332 tane Türk atasözü bulunmaktadır.

Mukayeseli Türkçe ve Fransızca Durûb-ı Emsâl' deki atasözlerinin seçimi ve düzenlenmesinde yazarın kişisel tercihleri ön plandadır. Bu tercih ve seçime göre eserdeki Türk atasözleriyle (tercüme olmayan) ilgili şunlar söylenebilir:

- Bazı atasözlerinin anlamına yakın atasözü karşılığı parantez içerisinde verilmiştir.

Örnek: Zurnayı biz çaldık, parsayı el topladı. (Biz cefayı çektik, eller sürdü sefay1.)

Çok gezen çok bilir. (Çok yaşayan çok bilmez, çok gezen çok bilir.)

- Ay yıldız motif içerisinde bazı Türk atasözleriyle benzer aynı kavram dünyasıyla ilgili olan atasözlerinin yer aldığı örnekler vardır. Bu kavram alanlarının 26 farklı temaya göre sırası şu şekildedir: "Temkinlilik, kötülük, anne-kız ilişkisi, kıskançlık-açgözlülük, huy, rekabet, güven, tek başınalık, alacak/verecek, sözün önemi, azim, zamanın geri alınamayacağı, acele iş, tevekkül, sessizlik, para, zaman, söz, tek olmanın gücü, bilmek, sabır, davranış, anlamak, ders alma, kanaat, fiziki görünüm.”

Örnek: Varlığa darlık olmaz.

Altın anahtar kale kapılarını açar. / Altın eli bıçak kesmez. / Çık çık eden nalçadır, iş bitiren akçedir. / Rağbet güzel ile zengindir. / Parayı veren düdüğü çalar. / Derviş para ile biter her iş. / Zengin arabasını dağdan aşırır, züğürt ovada yolunu şaşırır. / Akçesi ak olanın bakma yüzün karasına. / Akçeli adamdan dağlar korkar. Amasya'nın bardağı biri olmazsa bir daha.

El için kuyu kazan evvela kendi düşer. / Kişi ettiğini bulur. / Ne dilersen eşine o gelir başına. / Herkesin ettiği yoluna gelir. / Etme bulma dünyası.

- Bazı zarflar derlemeye alınmıştır.

Örnek: Karınca kararınca.

- Farklı zarf fiille derlemede yer alan örnek vardır.

Örnek: Üzüm üzüme bakarak kararır.

- Atasözlerinin bazılarının devrik yapıda olduğu görülür. 
Örnek: Ne etliye karışır ne de sütlüye.

Derviş para ile biter her iş.

- Bazı atasözlerinin eksiltili yapıda bırakıldığı örnekler yazılmıştır.

Örnek: İnsanın söylemezinden, suyun şarlamazından.

Her kafadan bir ses.

- Bugün var'la kurulu isim cümlesi örneklerinin yüklemsiz bırakıldığg örnekler vardir.

Her kemalin bir zevali, her zevalin bir kemali.

Her sefanın bir cefası, her cefanın bir sefası.

- Özlü sözler derlemede kendine yer bulmaktadır.

Örnek: Müsademe-i efkârdan barika-i hakikat çıkar.

- Günümüzdeki kullanımları farklı olan atasözlerine kitapta yer verilmiştir.

Örnek: Aşağı tükürsem sakalım, yukarı tükürsem bıyı̆̆ım.

- Günümüzde kullandığımız atasözlerinde yer alan bazı sözcüklerin eski eşanlamlılarının derlemede yer aldığı örnekler vardır.

İttihattan kuvvet doğar.

- Yazarın eserin karşılaştırmalı bir atasözü kitabı olması sebebiyle atasözünü daha anlışılır kılmak adına kendi tasarrufunda bazı eklemeler yaptığını düşündüğümüz örnekler mevcuttur.

Örnek: [Kişiye] bilmemek ayıp değil sormamak ayıptır.

[Kişi] ayağını yorganına göre uzatmalı.

[Ben öldükten sonra] taş taş üstünde kalmasın.

- Derlemede daha önce şiir olarak söylenmiş fakat artık atasözü hüviyetinde yer alan örnekler bulunmaktadır.

Örnek: Ayinesi iştir kişinin lafa bakılmaz. / Şahsın görünür rütbe-i aklı eserinde. Tiz-i reftar olanın payine damen dolaşır. / Erişir menzil-i maksuduna aheste giden.

- Eserde, meşhur kimselerin söylediği beyitlerdeki her bir mısranın aynı kavram dünyasında olduğu düşünülmüştür.

Örnek: Acele işe şeytan karışır. / Tiz-i reftar olanın payine damen dolaşır. / Erişir menzil-i maksuduna aheste giden. 
- Bazı deyimler atasözü derlemesine alınmıştır.

Örnek: At alan Üsküdar'1 geçti.

Halkın sesi, hakkın sesi.

- Kaynak kişisi belli olan bazı atasözlerine eserde yer verilmiştir.

Örnek: İtibar samur kürke.

Göz iki, kulak iki, ağız tek; çok görüp çok işitip az söylemek gerek.

- Bugün Türkçede az bilinen atasözlerine kitapta rast gelinmektedir.

Örnek: Karga bana söyledi.

Sanat altın bileziktir.

- Günümüzde çok sık kullanılan atasözleri derleme yer bulmaktadır.

Örnek: Gülü seven dikenine katlanır.

Köprüyü geçinceye kadar ayıya dayı derler.

- Bazı atasözlerinde yer alan sözcüklerin farklı varyantları parantez içinde gösterilmiştir.

Örnek: Alışmış (dadanmış) kudurmuştan beterdir.

Korku dağları aşırır. (bekler.)

- Eserde bazı atasözlerinin bugünün aksine farklı söyleyişleri kitapta yer almaktadır: Örnek: Köpeği an, çomağı yanı başında.

Bal bal demekle ağız tatlı olmaz.

- Ay yıldızlı motifler içerisinde derlemenin tamamında parantez içinde verilmeyen atasözlerinin sadece bir tanesi parantez içerisinde yazılmıştır.

Örnek: (Bir kapıyı bend ederse bin kapı eyler küşad.)

- Bazı mecazlara kitapta yer verilmiştir.

Örnek: İyi gün dostu.

Etme bulma dünyası.

- Atasözlerinin bazıları eksik sözcükle belirtilmiştir.

Örnek: Boş çuval durmaz.

- Soru cevap şeklinde yazılmış atasözü örneği vardır.

Örnek: Âlimi nasıl bilirsin kendin gibi. 
- Karşılıklı konuşma biçiminde söylenmiş atasözleri derlemede bulunmaktadır. Örnek: Dilenciye hıyar vermişler, eğri demiş.

Eşeği oduna çağırmışlar «ya odun eksik ya su» demiş.

- Bugün için farklı isim çekim ekleriyle kullanılan atasözlerinin kitapta eksiz yapıda kullanıldığı görülmektedir.

Örnek: At alan Üsküdar'1 geçti.

Akılsız başın zahmetini ayak çeker.

- Derlemedeki bazı atasözlerindeki sözcüklere fazladan eklenmiş isim çekim ekli örnek vardır.

Örnek: Günden doğmadan meşime-i şebten neler doğar.

- Mukayeseli Türkçe-Fransızca Durûb-ı Emsâl'de bazı Türkçe atasözlerine Fransızcanın dışında Arap atasözü karşılığının da verildiğine müşahede edilmektedir.

Örnek: Hüküm galibindir.

El hükmü li-men galebe.

\section{SONUÇ}

Atasözleri bir milleti millet yapan ögelerin içerisinde yer almaktadır. Tarihi çok eskilere dayanan Türk milletinin atasözlerine dair söz varlığı çok geniştir.

Atasözlerinin Orhun yazıtlarıyla başlayan Türk yazı dilindeki kullanımının günümüze kadarki izleri, İslamiyet öncesinde ve İslamiyet sonrasında pek çok eserde izlenebilmektedir.

Başlangıçta "sab-saw” terimiyle karşılanan atasözü terimi için günümüze kadar farklı adlar kullanılsa da Cumhuriyetle birlikte “atasözü” lafzı yaygınlık kazanmış ve diğer kullanımların önüne geçmiştir.

Fransız ihtilalinin yaydığı milliyetçilik akımı ve Tanzimatla birlikte başlayan yenileşme hareketleri, Türk atasözü çalışmalarına farklı bir boyut getirmiştir. Önceleri yazılan eserlerin arasına serpiştirilen atasözleri artık Şinasi ile birlikte müstakil kitaplarda toplanmaya başlamıştır. Hatta Türk atasözlerinin derlendiği çalışmaların yanına Türkçenin de içinde bulunduğu iki dilli atasözü derlemeleri ortaya çıkmıştır. Türkçenin yanında kendisine atasözü derlemelerinde yer bulan dil, XIX. asrın hâkim dili olan Fransızca olmuştur.

1888 yılıyla başlayan Türk ve Fransız atasözlerini derleme faaliyetinin 1928'den önceki son örneği, 1923 yılında İzzet Hamid tarafından yazılan Mukayeseli Türkçe ve Fransızca Durûb-ı Emsâl adlı eser olmuştur. Yazar, 1928'e kadar yazılan üç Türk-Fransız atasözleri kitabının en hacimlisine ve en bol örneklisine eseriyle imzasını atmıştır. 
İzzet Hamid yazdığı eserin hem derleyicisi hem de tercümanıdır. Kitapta farklı konulardaki atasözleri ay yıldız motifi içerisinde verilmiştir. Her motifin içerisinde önce Türk atasözü ve bunun Fransızca tercümesi, sonra da Fransız atasözü ve bu atasözünün Türkçe tercümesi yazılmıştır. Biz bu çalışmamızda ay yıldız motifin başında verilen ve tercüme olmayan Türk atasözlerine yer verdik.

Yazar, eserin başından sonuna kadar atasözlerinin seçimi, sınıflandırılması, karşılaştırılması vb. yollarda tamamen kişisel tercihlerine göre davranmaktadır. Davranışının nasıl olduğuna veya neye göre hareket ettiğine dair eserde ön söz dahil herhangi bir bilgi bulunmamaktadır.

Mukayeseli Türkçe ve Fransızca Durûb-ı Emsâl'de parantez içinde yakın anlamlı ve aynı temalı atasözleri de dahil olmak üzere tercüme olmayan toplamda 332 tane Türk atasözü yer almaktadır. Bu atasözlerinin tamamı incelendiğinde; yazarın atasözü/deyim/özlü söz ayrımına varamadığ 1 ve bu nedenle eserinde hem atasözlerine hem deyimlere hem de özlü sözlere atasözü başlığında yer verdiği, bugün için eksiltili olarak kullanılmayan atasözlerini eserinde eksiltili yapıda yazdığı, günümüzde tasarrufu farklı olan atasözlerinin isim çekim eki almadığı hâlleriyle gösterdiği, bazen atasözlerindeki kelimeleri eş anlamlılarıyla değiştirdiği, bazı atasözlerinin farklı versiyonlarına değindiği, derlemesine aldığı bazı örneklerde zamanına kadar meşhur olmuş beyitleri ve mısraları aldığı, devrik yapıdaki bazı atasözlerinin derlemede mevcut olduğu, tercümeden kaynaklı bazı sözcüklerin yazar tarafından atasözlerine eklendiği, kitaptaki atasözlerinin bazılarının söyleyenin belli olduğu, bugün için Türkiye Türkçesindeki kullanımı hem çok hem de az olan atasözlerine eserinde yer verdiği anlaşılmaktadır.

Hakem Değerlendirmesi: Dış bağımsız.

Çıkar Çatışması: Yazar çıkar çatışması bildirmemiştir.

Finansal Destek: Yazar bu çalışma için finansal destek almadı̆̆ını beyan etmiştir.

Peer-review: Externally peer-reviewed.

Conflict of Interest: The author has no conflict of interest to declare.

Grant Support: The author declared that this study has received no financial support.

\section{KAYNAKÇA/REFERENCES}

Aslan, M. (2017). Osmanlıdan Cumhuriyete bir muhasebe düşünürü: İsmail Hamid (1861-1931). Muhasebe ve Finans Tarihi Araştırmaları Dergisi, 13(13), 1-7.

Aray, S. (1959). Bir Galatasaraylının hatıraları. Ankara: TBMM Basımevi.

Banarl1, N. S. (2004). Resimli Türk edebiyatı tarihi. İstanbul: MEB.

Bozkurt, E. ve Karadağ, A. B. (2013). Fransızca-Osmanlı Türkçesi atasözleri kitapları üzerine karşılaştırmalı bir inceleme. Turkish Studies-International Periodical For The Languages, Literature And History Of Turkish Or Turkic Volume, 8(10), 175-183.

Caferoğlu, A. (1929). Orhun âbidelerinde atalar sözü. Halkbilgisi Haberleri, 1(3), 43-46.

Çoşkunlar, Ş. N. (1961). Yeni yayınlar, Aylık Bibliyografya Dergisi, 6-7 cilt. 
Çotuksöken, Y. (1983). Atasözlerimiz. (3. bs). İstanbul: ASY.

Eminoğlu, E. (2010). Türk dilinin sözlükleri ve sözlükçülük kaynakçası. Sivas: Asitan Yayıncılık.

Ercilasun, A. B. (2020). Divanu Lugati 't-Türk'teki şiirler ve atasözleri. Ankara: Bilge Yayınc1lık.

Eyüboğlu, E. K. (1973). Şiirde ve halk dilinde atasözleri ve deyimler, İstanbul: Doğan Kardeş Matbaacıllk Sanayi AŞ.

İzzet Hamid (1923). Mukayeseli Türkçe ve Fransızca durub-ı emsal. İstanbul: İkdam Matbaası.

Oktay Aras Kitaplığg1. (2020). İzet Hamid Ün. http://www.oktayaras.com/izzet-hamitun/ tr/29172? fbclid=IwAR2ArGjUhY8LXbaVW92Iwk8J4y0ThSv9Aic6Sk5GbGwa5qcT0UmdUG2ttPk. $(15.09 .2020)$

Özemre, A. Y. (2006). Galatasarayı Mekteb-i Sultânî sinde sekiz yılım. İstanbul: Kubbealtı Neşriyatı.

Şentürk, A. (2007). Osmanlı şiiri antolojisi. (3. bs). İstanbul: YKY.

Şentürk, A., Kartal, A. (2007). Eski Türk edebiyatı tarihi. (4. bs). İstanbul: Dergah.

Zülfikar, H. (1988). Ata sözü terimi, kaynağı ve imlâsı. Türk Dili, 55(438), 321-328. 
